\title{
A Functional Analysis of the Finnish 2012 Presidential Elections
}

\author{
Laura Paatelainen ${ }^{1}$, Stephen Croucher $^{2}$, Bill Benoit ${ }^{3}$ \\ ${ }^{1}$ Doctoral Student in Speech Communication at the University of Tampere, Finland \\ ${ }^{2}$ Professor of Intercultural Communication at the University of Jyväskylä, Finland \\ ${ }^{3}$ Professor of Communication at Ohio University, USA \\ Correspondence: Stephen Croucher, Professor of Intercultural Communication at the University of Jyväskylä, Finland.
}

Received: August 22, 2016 Accepted: September 7, 2016 Online Published: September 21, 2016

doi:10.11114/smc.v4i2.1826 URL: http://dx.doi.org/10.11114/smc.v4i2.1826

\begin{abstract}
This study applied the functional theory of political campaign discourse, developed for political campaigns in the United States to two televised presidential debates in the 2012 presidential elections in Finland. Acclaims were the most preferred statement by the candidates, with agreements being the least preferred. Policy was discussed more than character during the debates. General goals and ideals were used more frequently to acclaim than to attack. Results are generally consistent with the results of previous studies of presidential elections in the US and other countries. However, differences did emerge: the classical functional categories were supplemented by a new category, the role of the moderator as an attacker in the debate is emphasized, the significance of the diminishing role of the Finnish Presidency is of significance, and the fact that one of the two candidates was the first openly homosexual presidential candidate likely influenced the debates and the election.
\end{abstract}

Keywords: functional theory, political communication, presidential debates, chi-square

\section{Introduction}

Presidential elections are one of the most anticipated and high-profile events of a democratic society: Every few years, the people gather together and express their opinion on who should be the leader of their nation for the next several years. Presidential candidates do their best to distinguish themselves from one another and to present themselves in a positive light, and the people will try to make an informed decision on who, from their personal perspective, is the best candidate for the job. In making this important decision they are influenced by different forms of campaign messages that aim not only to provide information, but also to influence the voters' final decision. Perhaps the most important of these message forms is presidential debates.

Televised debates are extremely important (Benoit, 2007, 2014a, 2014b) due to their various advantages compared to other campaign message forms. Compared to, for example, a television spot or an advertisement aired on radio channels, televised debates give the candidates much more room to present their case and to distinguish themselves from one another. In debates, candidates are engaged in dialogue, which makes it easier for the voters to make comparisons between the candidates. Since candidates are usually not allowed to bring any notes to these debates, they offer voters a chance to see a more spontaneous side of them. Finally, debates usually generate a lot of attention both from media and from general public, which means increased public discussion that ultimately benefits the voters (Benoit, 2007, 2014a, 2014b). Several studies on the effects of watching televised debates indicate that not only does watching these debates increase the knowledge of the voters, but also has the capability of affecting their final voting decisions, especially in cases where they were originally undecided (e.g., Benoit, Hansen, \& Verser, 2003; Lemert, 1993; McKinney \& Warner, 2013; Pfau, 2002; Schrott, 1990). Therefore, it is clear that televised presidential elections merit scholarly attention.

In this research the functional theory of political campaign discourse, developed by Benoit and his colleagues (e.g., Benoit, 2007, 2014a, 2014b; Benoit, Blaney, \& Pier, 2000), will be applied to analyse the televised presidential debates of the 2012 presidential elections in Finland. Functional Theory makes a series of assumptions and predictions on the utterances performed by candidates in their campaign discourse and has been used to analyse presidential debates in the United States (Benoit, 2014b), among other forms of campaign messages, which include television spots, direct mail advertising and talk show appearances. The theory has also been applied to presidential elections in other countries with mixed results: most studies seem to indicate presidential campaign discourse is the same across borders and cultures, 
yet a few studies (e.g., Cmeciu \& Patrut, 2010; Hrbková \& Zagrapan, 2014; Isotalus, 2011) have offered criticism of the theory, claiming it to be too culturally limited to be useful in cultures different from the United States. Isotalus (2011) applied the functional theory to Finnish elections, analysing the 2006 presidential elections in Finland. He criticized the theory for not being applicable in multi-party systems and for not being suitable for analysing political campaign discourse in Finland, as the Finnish speech culture differs greatly from the American speech culture. It is possible that cultural differences influence the content of political leaders' debates. However, Functional Theory has been successfully applied to debates in multi-party systems: Australia, Canada, Northern Ireland, Scotland, the United Kingdom, and Wales (see Benoit, 2014b).

Even though the functional theory of political campaign discourse has been applied to Finnish presidential debates, there are strong reasons for conducting another study. First, applying the theory to another set of presidential debates in the same country helps to determine whether the results of the first study are really caused by cultural differences or whether they were only applicable to one set of debates. Second, the Finnish political system offers an interesting opportunity to study political leaders' debates. In the United States the president is clearly in charge of running the government; however, in Finland the president has in recent years been stripped from a large amount of political power. Instead of running the government, the president is seen as a "symbol of the nation", somebody who represents the core values of the country and is in charge of international relations of the country (Halonen, 2002) - again, symbolically, as for example the matters concerning the European Union are mainly handled by the Prime Minister and the government. Third, the 2012 presidential elections in Finland were particularly interesting and deserve a closer analysis, which has not been provided so far. In the 2012 elections there was no incumbent candidate, as President Tarja Halonen was leaving office. Out of the eight candidates, Mr. Sauli Niinistö was predicted by many as the clear winner (Kinnunen, 2011). Nevertheless, the elections preceded to a second round, where Mr. Niinistö was challenged by Mr. Pekka Haavisto - the first openly homosexual candidate in the history of Finland. In the end, the 2012 presidential elections was an election of values and ideals. Many voters, especially younger ones, voted for Mr. Haavisto simply for the reason of wanting to support gay rights in Finland. Some people also voted Mr. Niinistö for the same reason: They did not want to have a homosexual president in Finland (Blencowe, 2012). Therefore, although one of the assumptions made by the functional theory of political campaign discourse is that in presidential elections, policy issues matters more than the character of the candidates; in this particular set of elections it is clear that character and personal attributes played a decisive role.

The research reported here will serve as an analysis of the political campaign discourse in the context of Finnish presidential elections. In addition to that, it will also serve as a cultural comparison, where the results of this Finnish analysis will be compared to those of studies conducted in the United States and other countries.

\section{Literature Review}

This section presents a review of the research on televised political leaders' debates. A large portion of the research is focused on analysing presidential elections in the US. This US-focused research includes analysis of the language and rhetoric of presidential debates (e.g. Cienki, 2004; Halmari, 2008; Peifer \& Holbert, 2013; Rhea, 2012), argumentation strategies (e.g. Hollihan, 2009; Roitman, 2015; Straub, Beller, \& Hunt, 2012; Zarefsky, 2008;), issue ownership (e.g. Benoit \& Hansen, 2004; Cole \& Hawthorne, 2013) and effects of political leaders' debates on issue knowledge and voter behaviour (e.g., Benoit \& Hansen, 2004; Benoit et al., 2003; Benoit, McKinney \& Stephenson, 2006; Pfau, 2002). According to these studies televised debates increase issue knowledge and influence voters' perception of the candidates and voter behaviour, especially in situations where voters were undecided before watching the debates.

Benoit's (e.g., 2007, 2014a, 2014b; Benoit, Webber, \& Berman, 1998; Benoit, Pier, Brazeal, McHale, Klyokovski, \& Airne, 2002; Benoit et al., 2003) functional theory on political campaign discourse is one of the most used theories in research of televised political leaders' debates. The theory is focused on analysing the content of the campaign messages and classifying that content into attacks, acclaims, and defences - as well as into policy and character utterances -according to what the candidates said, thus resulting in better understanding of "tactics" employed by the campaigning politicians. The functional theory has been applied to many different kinds of campaign messages in the US, including debates ranging from presidential primary debates, general election debates, vice-presidential debates, senate debates, gubernatorial debates, and mayoral debates (see Benoit, 2014b). The results of these studies are similar: in presidential election debates, acclaims are generally used more than attacks, which are used more than defences, and policy is discussed more than character. The challengers use more attacks than incumbents, who are more prone to using acclaims (Benoit, 2014b). Also the results of research on other campaign mediums - web pages, radio spots, television spots, talk show appearances, and convention speeches - seem to follow a similar pattern (Benoit, 2007).

The functional theory of political campaign discourse was originally designed to analyse election campaigns in the United States (Benoit, 2007). In recent years, however, the functional theory of political campaign discourse has been 
applied to several elections in various countries outside of the US. So far, functional theory has been used to analyse political campaign discourse in Slovakia (Hrbková \& Zagrapan, 2014), the United Kingdom (Benoit \& Benoit-Bryan, 2013), France (Choi \& Benoit, 2013), Spain (Herrero \& Benoit, 2009), Israel (Benoit \& Sheafer, 2006), Taiwan (Benoit, Wen, \& Yu, 2007), Romania (Cmeciu \& Patrut, 2010), Ukraine (Benoit \& Klyukovski, 2006), Germany (Benoit \& Hemmer, 2007), Korea (Lee \& Benoit, 2004, 2005), Finland (Isotalus 2010, 2011), Canada (Benoit, 2011; Benoit \& Henson, 2007), and Australia (Benoit \& Henson, 2007). Applying functional theory to research the political campaign discourse in countries other than the US has raised the question of whether the theory is too culturally limited to be useful in political systems different from that of the US. Critique towards the functional theory has been brought forward by Isotalus $(2010,2011)$ who claims, first, the theory was developed to be used in a two-party system and is therefore difficult to apply to a multi-party system, second, the functional theory only works in elections where the character of the candidate is important (Isotalus \& Aarnio, 2005 in Isotalus, 2011) and third, some forms of political discourse are culturally bound and therefore the division to attacks, acclaims and defences is not flexible enough to analyse political campaign debates in all cultures. Cmeciu and Patrut (2010) agreed with this critique, arguing that political campaign discourse is not consistent across borders and cultures; indeed, their study of the 2009 Romanian presidential debates revealed the debates were not focused on acclaims and policy, as argued by the functional theory, but instead on attacks and defences. Also Hrbková and Zagrapan's (2014) research of the 2012 election debates in Slovakia reached similar conclusions, arguing the categories of content analysis should be expanded as with the current categories more than 30 percent of the content of the debates would be excluded from the analysis - an argument also made by Isotalus (2011). Nevertheless, from the content analysed, acclaims were still the most common category, followed by attacks, which means the results reached in Slovakia are at least somewhat similar to those reached in the United States. A different result was reached in the Ukraine (Benoit \& Klyukovski, 2006) where attacks were more common than acclaims; however, this unusual result is at least partly due to the exceptional nature of this Ukrainian campaign (the campaign included voter fraud as well as accusations of one candidate poisoning the other).

In Finland, televised presidential debates - sometimes called discussions in the media - are still a relatively understudied phenomenon. Research has been done on argumentation in presidential debates (Kaija \& Malinen, 2007), communication style (Kuivasmäki, 2000; Tiittula, Nuolijärvi \& Isotalus, 2007), and constructing the candidate's identities (Halonen, 2000). Isotalus $(2009,2011)$ applied the functional theory of political campaign discourse to the analysis of Finnish presidential debates in 2006; he stated that although generally the results correspond to the results found in US, the theory itself is not a suitable tool for analysing Finnish presidential debates, as so many utterances are left unanalysed. Nevertheless, with so little attention being given to content analysis of Finnish presidential debates, another look is warranted.

\section{Theoretical Underpinning}

The functional theory of political campaign discourse, developed in the US by Benoit (2007, 2014a, 2014b; Benoit et al., 1998, 2002, 2003) provides the theoretical foundation for this study. The theory is based on the idea that political campaign messages are always inherently functional in their very nature, as they are delivered to achieve one purpose: the winning of elections. This is most likely true in two-party systems, where both candidates have a reasonable chance of winning the debate; however, as acknowledged by Benoit (2007), it is possible that sometimes in the elections there are candidates who do not stand a chance of winning the elections and who therefore use the campaign to fulfil some other purpose, such as laying groundwork for the next elections or furthering the agenda of their own party. This theory presents five different assumptions or axioms that lay the groundwork for the theory: first, voting is a comparative act, second, candidates must distinguish themselves from their opponents in a positive light, third, political campaign messages allow candidates to distinguish themselves, fourth, candidates establish preferability through acclaiming, attacking and defending, and fifth and finally, campaign discourse occurs on two topics: policy and character. The underlying idea is that candidates can only seem preferable to other candidates if they seem different - if all the candidates were indistinguishable, no one would know who to vote for, and the voter turnout would probably hit record lows. Candidates can make themselves look more preferable either by highlighting their own strengths (by acclaiming and defending) or pointing out the weaknesses of their opponents (by attacking). This can happen either on the level of policy (governmental action and problems amenable to such an action) or character (the characteristic or qualities of the candidates.) Both policy and character are then divided into three further categories for closer analysis: policy can be discussed either on the level of past deeds, general goals or future plans, and character can focus on personal qualities, leadership abilities, and ideals. This study tests four hypotheses derived from the functional theory and confirmed through previous research (e.g., Benoit \& Benoit-Bryan, 2013; Benoit, Delbert, Sudbrock, \& Vogt, 2010; Benoit et al., 2011; Benit, Henson, Davis, Glantz, Phillips, \& Rill, 2013; Brazeal \& Benoit, 2001, 2006).

According to the functional theory, acclaims are the "safest choice" for candidates: they highlight the best qualities of the candidates without having any visible drawbacks (this does not mean all acclaims are persuasive, just that acclaims 
have fewer drawbacks than the other two functions). Attacks can be useful in highlighting the weaknesses of other candidates, yet they have their dangers too: studies have shown voters dislike "mud-slinging," so too many attacks or badly timed attacks may cause the voters to turn on the candidate making these attacks. Compared to the other two, defences are said to be the least useful function: Although they can help to reduce damage made by an attack or to restore the candidate's damaged image (Benoit, 2007), they also force the candidates to draw more attention to the attack in the first place, reminding the voters of the attack. They also prevent the candidates from using the time for other, more beneficial utterances, such as highlighting their strengths by acclaiming. Thus, based on theory and research about the function of acclaims and defences, the first hypothesis is proposed:

H1: Acclaims will be the most common function and defences will be the least common function in the 2012 Finnish presidential debates.

Previous research shows that in American presidential elections policy is discussed more than character (even $75 \%$ to 25\%). This result has also been confirmed in other countries (e.g., Choi \& Benoit, 2013). Therefore, based on the research suggesting differences in the frequency of policy and character discussion the second hypothesis is put forth:

H2: Policy will be discussed more than character in the 2012 Finnish presidential debates.

The reasoning for both hypotheses 3 and 4 is the same: General goals and ideals are both vague and unspecific in their very nature, so attacking them is more difficult than attacking for example very specifically laid out future plans. It can be difficult, and even harmful, to disagree with general goals such as "I want to reduce poverty in this country" or with ideals such as "I believe in equality", as the general population sees reducing poverty and equality as positive ideas. For this reason, both general goals and ideals are considered to be "safe" tools for acclaiming: the likelihood of backlash is relatively small, since attacking generally accepted ideas would be most likely to hurt the attacking candidate than the candidate being attacked. These results have been confirmed in previous research (e.g. Benoit 2007, 2011; Benoit \& Benoit-Bryan, 2013). Therefore, based on previous research, the following two hypotheses are presented:

H3: General goals will be used more frequently to acclaim than to attack in the 2012 Finnish presidential debates.

H4: Ideals will be used more frequently to acclaim than to attack in the 2012 Finnish presidential debates.

Originally, the functional theory of political campaign discourse also included two other hypotheses. Both of these hypotheses concern the role of the incumbent candidate in the debates. Since in the 2012 Finnish presidential elections there was no incumbent candidate, these two hypotheses (hypotheses 3 and 4 in the original theory) were not included in the analysis.

\section{Method}

This study analysed two Finnish presidential debates from 2012. Both of these debates took place in the second round of the 2011 presidential elections. Participants included the two remaining presidential candidates, Mr. Sauli Niinistö of the Coalition Party and Mr. Pekka Haavisto of the Green Party, as well as two moderators. The debates took place on January 26, 2012 and February 2, 2012 and were broadcast by YLE (Finnish public service broadcasting company). Both of the debates lasted an hour. There were also other televised debates arranged by other broadcasting companies; the debates broadcast by YLE were chosen because of the company's nature as a public service - and thus, deemed to be most objective - company. Debates also took place in the first round of the presidential elections with all the initial eight candidates; however, a decision was made to focus on the second round debates as they, with two remaining candidates, resembled more closely the format of the American presidential election debates. Due to this resemblance, it was possible to look past the differences between political systems (two-party vs. multi-party systems) and focus on the possible cultural differences between Finnish and American debates.

The data was analysed applying the same procedures used in previous studies using functional theory (e.g. see Benoit, 2007, 2014a, 2014b) and statistical significance was tested with chi-square test. The texts of these debates were divided into themes. Themes are complete ideas, arguments, or claims capable of expressing different functions. The length of a theme can vary from a single phrase to several sentences. Once the themes were identified, they were categorised by function: acclaims, attacks, defences, and agreements. Next, the themes were classified by topic: policy or character. Finally, policy utterances were divided further into utterances concerning general goals, past deeds, and future plans, and character utterances were divided personal qualities, leadership abilities, and ideals.

The original method was modified slightly to take into account some characteristics of these televised debates. Originally, the functional theory only consisted of three categories: acclaims, attacks, and defences. In this particular study, a fourth category called agreements was added. Isotalus (2011) claimed agreements are a characteristic typical to Finnish presidential debates; this category was added to examine this claim further. Second, the original method does not take into account the utterances made by the moderators as they do not play a meaningful role in the debates. In the Finnish presidential debates, however, the role of the moderators is very visible. Their questions are guiding the 
discussions, and they are even actively making attacks against the candidates. Since these attacks frequently forced the candidates to defend themselves, it was decided they should be included in the analysis. All the other utterances made by the moderators were left unanalysed.

\section{Context of the 2012 Finnish Debates}

Finland is a parliamentary democracy, in which parliament is formed by multiple parties and governed by the Prime Minister. Unlike in a presidential system, in Finland the president has relatively little political power; the tasks of the president have been reduced several times, the latest of which took place in 2000 and left the president with little political power mainly consisting of international relations. However, even in that field the tasks of the president are restricted: for example matters concerning the European Union are mainly handled by the Prime Minister (Halonen, 2002). It has been claimed that these days the role of the president in Finland is mostly symbolic, that of representing the nation and its values to the outside world (Halonen, 2002). Nevertheless, there are still those in Finland who long for a strong president to lead the country and its politicians (Halonen, 2002).

The president is elected every six years and can have two consecutive terms of office. The president is elected through a direct vote. Since Finland is a multi-party system, there are always several candidates. Should one of these candidates get more than 50 percent of the votes in the first round, that candidate is elected president. If none of the candidates get more than half of the votes, the elections proceed to a second round, in which the president is elected among the two candidates who gained the most votes in the first round. Usually the second round is needed before a winner can be determined. Even though the president has relatively little political power, presidential elections matter: ever since the late 1980's, the voter turnout at presidential elections has been about 10 percent higher than in parliamentary elections (Moring, 2008, in Isotalus, 2011). One possible reason is the people still perceive the president as their leader. Another reason might be the fact that voting for president is considered to be "easier" than voting in the parliamentary elections as there are fewer candidates to choose from.

In the 2012 presidential elections in Finland there were originally eight candidates, none of whom was the incumbent as President Tarja Halonen was leaving the office after two consecutive terms. A clear favourite according to the polls was Mr. Sauli Niinistö from the National Coalition Party (Yle, 2012). Despite this, in the first round he received less than 50 percent of all votes, which meant the elections proceeded to the second round. In the first round, Mr. Niinistö got 37 percent of the votes, followed by Mr. Pekka Haavisto from the Green Party $(18.8 \%)$ and Mr. Paavo Väyrynen from the Centre Party (17.5\%). The other candidates - Mr Timo Soini from True Finns (9.4\%), Mr Paavo Lipponen from the Social Democratic Party of Finland (6.7\%) Mr. Paavo Arhinmäki from the Left Alliance (5.5\%), Mrs. Eva Biaudet from Swedish People's Party of Finland (2.7\%) and Mrs. Sari Essayah from the Christian Democrats $(2.5 \%)-$ were left far behind (Statistics Finland, 2012). In the second round of the elections, Mr. Niinistö was challenged by Mr. Haavisto, but still managed to win the elections as expected with a clear result, 62.6 percent of all votes compared to Mr. Haavisto's 37.4 percent.

In the 2012 presidential campaign there were two distinct features. First, Mr. Sauli Niinistö was a clear favourite throughout the whole campaign - so much so that it most likely affected the overall campaign. It is likely that with such a clear winner, most of the other candidates were not really campaigning with the goal of winning the election, but had other aims in mind, such as gathering more support for their party or laying the groundwork for future elections. It has also been noted that in the first round of the election debates, Mr. Niinistö's performance was quite lacklustre (eg. Hallamaa, 2012; Iranto, 2012). It could be asked whether his position as the predicted winner meant that he did not see the need for campaigning. Second, the 2012 presidential elections were the first elections in Finland with an openly homosexual candidate: Mr. Pekka Haavisto from the Green Party, who eventually proceeded to the second round of the elections with Mr. Niinistö. According to estimates it is clear Haavisto's sexual preference was a central factor with the elections, with many people choosing to vote for his rival because they were not ready to have an openly homosexual president in the country (Blencowe, 2012). Similarly, many people rallied to vote for Haavisto because they wanted to show support for gay rights in Finland. This challenges the assumption made by the functional theory of political campaign discourse that policy matters more than character: clearly, in the 2012 presidential elections in Finland, personal characteristics, not political expertise, were a decisive factor (Blencowe, 2012).

\section{Results}

A total of 331 turns were coded. These included all of the turns of the candidates (Niinistö, 153 turns, Haavisto, 144 turns) as well as attacks uttered by moderators (34 turns). Most of these turns could be categorised into functions; however, 91 of the turns $(28 \%)$ could not be categorized into these categories. Each utterance was classified as policy or character. Policy comments were further divided into past deeds, future plans, and general goals. Character themes were subdivided into personal qualities, leadership ability, and ideals.

Hypothesis 1 predicted acclaims would be the most used function in the Finnish presidential debates, followed by 
attacks and finally, defences. In the analysed debates, there was a significant difference between the different functions: $\chi^{2}(d f=2)=98.29, p<.0001$. Overall, acclaims were the most preferred statement by the candidates $(n=120)$, with agreement being the least preferred $(n=15)$. The results can be seen in Table 1 . In the first debate, Niinistö made an acclaim concerning his character and personal qualities:

My reason for participating in these elections from the very beginning has been the strong knowledge that I have the capability of dedicating myself to what I'm doing at any specific moment, and I believe I have lots to give when it to making sure that good life will exist in Finland also in the future. That is the goal I want to serve and I dedicate to that task.

However, it should be taken into account that most of the attacks recorded were actually made by moderators $(67 \%)-$ should the attacks made by moderators be left out, the results would be different, with acclaims being the most used function, defences the second and attacks the third. In the following passage, one of the moderators attacked Haavisto:

It is said about you, Pekka Haavisto, that you know people from the Russian opposition and non-governmental organisations, but you do not have any ties to the Russian leadership in Kreml. Just what kind of president would you when you do not even have any ties to Kreml?

The attacks made by moderators were often very direct, while the attacks made by the candidates themselves were not so direct. The candidates would for example disagree with facts presented by the other candidate, or question their abilities in some other way. In the following passage, Haavisto attacked Niinistö about the funding of his campaign:

Well dependability is, I'm not accusing you Sauli about anything, but the fact is that when one has a lot of big it does bring into mind the question that what is the interest of these large companies, and president's trade promoting functions and so on.

Even though Haavisto claimed he is not making any accusations, the paragraph above is clearly an attack questioning Niinistö's integrity and financial dependability. Finally, Isotalus (2011) suggested that agreements are an important function of Finnish presidential debates. In the debates analysed, agreements formed $5 \%$ of all the turns, indicating they are used to some extent, but other functions are still much more common.

Table 1. Functions of the 2012 Finnish presidential debates

\begin{tabular}{lllll}
\hline & Acclaims & Attacks & Defences & Agreements \\
\hline Niinistö & $53(35 \%)$ & $10(7 \%)$ & $29(19 \%)$ & $8(5 \%)$ \\
Haavisto & $68(47 \%)$ & $7(5 \%)$ & $22(15 \%)$ & $7(5 \%)$ \\
Moderators & - & $35(67 \%)$ & - & - \\
Total & $120(36 \%)$ & $52(16 \%)$ & $51(15 \%)$ & $15(5 \%)$ \\
\hline
\end{tabular}

Hypothesis 2 predicted policy would be discussed more than character. This was supported: with a significant difference between the topics: $\chi^{2}(d f=1)=90.30, p<.0001$. As predicted, policy $(n=142)$ was discussed more than character $(n$ 76). 22 turns $(30 \%)$ could not be classified into either policy or character, corresponding with the percentage of turns not categorised into functions. $44 \%$ of Niinistö's utterances concerned policy and 19\% concerned character $(37 \%$ uncategorised), while Haavisto discussed policy in 54\% of his turns and character in $15 \%$ of the turns (31\% uncategorised). The results of this can be seen in Table 2. Both policy and character were also topics of attacks made by moderators: policy was used in $14 \%$ of the moderators' attacks, while character was the topic of $69 \%$ percent of these attacks. The rest of the attacks could not be assigned into either of these topic categories. One of the moderators provided an example of a character-focused attack:

Last Sunday at the election results party you said that everyone needs someone in their house who cooks for them, their shirts and takes care of them. Now you've had to many give explanations for this statement. Did you accidentally happen to reveal something real about your attitude, Sauli Niinistö?

Table 2. Topics of 2012 Finnish presidential debates

\begin{tabular}{lll}
\hline & Policy & Character \\
\hline Niinistö & $67(44 \%)$ & $29(19 \%)$ \\
Haavisto & $78(54 \%)$ & $22(15 \%)$ \\
Moderators & 6 & 18 \\
Total & $151(46 \%)$ & $79(24 \%)$ \\
\hline
\end{tabular}

Hypothesis 3 predicted general goals would be used more frequently to acclaim than to attack in the 2012 Finnish general presidential debates. This hypothesis was supported: $\chi^{2}(d f=1)=15.16, p<.05$. As predicted, general goals $(n$ $=131)$ were used more frequently to acclaim $(n=94)$ than to attack $(n=13)$. These results can be seen in Table 3 . 
Table 3. Subtopics of the Finnish 2012 presidential debates

\begin{tabular}{lllll}
\hline Functions & Acclaims & Attacks & Defences & Agreements \\
\hline Subtopic & & & & \\
Past deeds & $5(5 \%)$ & $2(13 \%)$ & $3(20 \%)$ & $0(0 \%)$ \\
General Goals & $94(95 \%)$ & $13(87 \%)$ & $11(73 \%)$ & $13(100 \%)$ \\
Not categorised & $0(0 \%)$ & $0(0 \%)$ & $1(7 \%)$ & $0(0 \%)$ \\
Total & 99 & 15 & 15 & 13 \\
\hline
\end{tabular}

Hypothesis 4 predicted ideals would be used more frequently to acclaim than to attack in the 2012 Finnish general presidential debates. This hypothesis was supported: $\chi^{2}(6)=16.28, p<=.05$. As predicted, ideals $(n=14)$ were used more frequently to acclaim $(n=8)$ than to attack $(n=3)$. These results can be seen in Table 4 .

Table 4. Use of ideals in the Finnish 2012 presidential debates

\begin{tabular}{|c|c|c|c|c|}
\hline & Functions & Acclaims & Attacks & Defences \\
\hline \multicolumn{5}{|l|}{ Subtopics 2} \\
\hline Leadership ability & & $6(29 \%)$ & $7(26 \%)$ & $9(30 \%)$ \\
\hline Personal qualities & & $5(24 \%)$ & $17(63 \%)$ & $18(60 \%)$ \\
\hline Ideals & & $8(38 \%)$ & $3(11 \%)$ & $3(10 \%)$ \\
\hline Not categorised & & $2(10 \%)$ & $0(0 \%)$ & $0(0 \%)$ \\
\hline Total & & 21 & 27 & 30 \\
\hline
\end{tabular}

Coding the turns to different functions was challenging. Although categorising themes into defence and agreements was fairly easy, a broader approach had to be taken with acclaims and attacks. In Finnish debates, candidates rarely made clear statements declaring a certain course of action they would take up as a president (such as "I will cut the taxes" or "I will decrease unemployment"). Instead, they expressed their opinion on policies they generally perceived as desirable or on the direction they would like to see the country to go in the future. In the context of this study, these were nevertheless classified as acclaims, as they were understood to be policies the candidates would drive forward should they have the opportunity. The same perspective was applied to attacks: even utterances that were not direct attacks would be classified into that category if they contained a clear criticism or challenge towards the other candidate.

A notable amount of turns could not be classified into any category. These included, among others, jokes made by the candidates, reacting to Twitter comments made by audience members, as well as analysing the current political situation in globally or in Finland. For example:

I think we need to be very careful when it comes to these terms. Binding ourselves to the West is too broad a term, it includes two different elements. Since we joined the EU this old term called neutrality is no longer so relevant, because as EU members we do express our opinions, we express our opinions on the crisis in Libya, we express our opinions on Iran and so on.

Although statements such as these cannot be categorised as acclaims, they nevertheless do have a role in painting a picture of the candidate as an expert on national and global politics, which might cause voters to see them in a more favourable light. In future studies it might be interesting to add another function - expressions of expertise - to research these turns further.

\section{Discussion}

The results of this analysis are generally consistent with the results of previous Functional Theory studies of presidential elections in the United States and other countries: Candidates used acclaims more than attacks or defences and policy was discussed more than character. However, some differences did emerge. Most of the attacks were uttered by the moderators, meaning that the candidates themselves used more defences than attacks. It is possible the reason for this difference lies in the different formats of the presidential debates; in the Finnish debates, the moderators are clearly in charge of the discussion, asking questions and making attacks against the candidates. This situation forces the candidates to react to the questions and attacks posed by the moderators and leaves them with relatively little room to engage in a direct discussion with one another - thus they simply do not have the time to attack each other. Another reason might be the fact that Niinistö was predicted as the clear winner throughout the whole campaign - perhaps the candidates did not see any point in making attacks, when the results seemed to be already decided. This is even hinted at by Niinistö in one of the debates when he, accused by one of the moderators as having been more quiet than normal, states that he sees little point in fighting with the others for the second place, when the results are already clear.

Policy was discussed more than character in the Finnish debates. While this result again correlates with the results from the US, it is slightly contradictory with statements from election experts, in which they claim that character, in fact, was the decisive factor in the 2012 election: namely the facts that Haavisto is homosexual, does not belong to any church and never served in the army, but opted for civil service instead (Blencowe, 2012). These are all questions of personal values, and while they were discussed shortly in the debates, much more time was dedicated for discussion of policy. 
This is also interesting considering the fact that in Finland, president has little say over any actual policies. President has, for example, the duty to confirm Acts into laws, but Acts can be entered into force even without the president's confirmation - leaving legislative power essentially in the hands of the government and the parliament. Also all significant decisions in the area of foreign policy made by the president must be done in accordance with the government. With president's power in Finland being mostly symbolic, it could be questioned why so much of the discussion still happens on the level of policy.

The president's diminished duties and power are also likely visible in the way policy is discussed in these debates. An overwhelming amount (85\%) of all policy utterances were made on the level of general goals; only $6 \%$ of the utterances focused on past deeds, and future plans were not discussed at all. While the difference between general goals and future plans also exists in the US debates, it is not as drastic as in the Finnish debates. In the United States it is still possible to see candidates making promises to cut taxes or to increase the military spending, yet in the Finnish debates analysed, this did not happen. The most likely reason is the president's limited power in Finland: there is little point for the candidates to present elaborate future plans for their turn as a president when they do not possess the political power to make those plans into reality. Instead, it makes much more sense to discuss on the level of general goals - policies that the candidates see as generally desirable, at the same time acknowledging that they might not be able to act on those policies. This was again demonstrated by Niinistö in one of the debates where he first outlines his view of the economic situation in Finland and the direction he would like to see it go and then reminds the audience that the president does not have the power to decide on matters of economics in Finland.

Perhaps the clearest difference between the presidential debates in the US and in Finland is the number of themes that did not fit into any category. In the presidential debates in the US the percentage of themes left uncoded is very small; in the debates analysed here, the portion is larger (28\%). Isotalus (2011) produced similar results. Isotalus $(2010,2011)$ claimed that agreements form a large portion of the themes left uncoded. However, the analysis here shows that the portion of agreements is not all that significant: only $5 \%$ of all the turns coded, meaning that even with agreements, the percentage of uncoded turns would not be more than $33 \%$. Therefore, the majority of the uncoded turns still consist of something else besides agreements. To some extent, these turns are "empty speech" - jokes, reactions to comments from audience et cetera. However - as has been noted by Isotalus $(2010,2011)$ earlier, these turns also include something that could perhaps best be characterised as "analysis of the current political / economic / societal situation in Finland/globally." The candidates not only made these analysing statements themselves, but also questioned the accuracy of the other person's analysis or facts. In this sense it could be argued that these analyses serve a purpose in political campaign discourse: the candidates attempt to paint a picture of themselves as experts as well as question the expertise of the other candidate(s), in a way attempting to claim to have the right narrative on how the world works. While these expressions of expertise have not been reported to appear in the US presidential debates, it is possible that they are a meaningful part of Finnish political campaign discourse and should be paid attention to in the future.

\section{Conclusions}

This study indicates there are both similarities as well as differences between the political campaign discourse of presidential debates in Finland and the US. However, neither earlier research nor the scope of the present study provides sufficient information on the significance of these differences: more research on the Finnish presidential debates would have to be conducted to determine whether the differences exist in all debates or whether they are simply a part of this particular campaign. The 2012 campaign was special for many reasons: the predicted clear victory for Mr Niinistö, the existence of an openly homosexual candidate and the historically low voter turnouts. Based on the special nature of the campaign, it would be presumptuous to assume that the results could be generalised to all presidential campaigns in Finland.

In this research, debates from the second round of the elections were chosen because their format resembled more closely the format of the US presidential debates. In the future, it could be interesting to analyse the debates from the first round of elections, with all the eight candidates present, and see whether there is any difference in the results. Another interesting possibility would be to study debates from the second round of 2012 elections, broadcast by different commercial broadcasting companies. These debates by different broadcasting companies might also have different formats, which could possibly be helpful in trying to determine the extent to which these differences are caused by formats, and to which extent they are caused by actual cultural differences. This would also help to determine whether the functional theory of political campaign discourse is a suitable tool for analysing Finnish presidential debates, or whether it would need to be modified to suit the context better. 


\section{References}

Benoit, W. L. (2007). Communication in political campaigns. New York, NY: Peter Lang.

Benoit, W. L. (2011). A functional analysis of the 2011 English language Canadian Prime Minister debates. Contemporary Argumentation \& Debate, 32, 45-69.

Benoit, W. L. (2014a). A functional analysis of presidential television advertisements ( $2^{\text {nd }}$ ed.). Lanham, MD: Lexington Books.

Benoit, W. L. (2014b). Political election debates: Informing voters about policy and character. Lanham, MD: Lexington Books.

Benoit, W. L., \& Benoit-Bryan, J. M. (2013). Debates come to the United Kingdom: A functional analysis of the 2010 British Prime Minister election debates. Communication Quarterly, 61, 463-478. http://dx.doi.org/10.1080/01463373.2013.799513

Benoit, W. L., \& Hansen, G. J. (2004). Presidential debate watching, issue knowledge, character evaluation, and vote choice. Human Communication Research, 30, 121-144. http://dx.doi.org/10.1111/j.1468-2958.2004.tb00727.x

Benoit, W. L., \& Hemmer, K. (2007). A functional analysis of German Chancellor debates. Conference Paper. International Communication Association: 2007 Annual Meeting.

Benoit, W. L., \& Henson, J. R. (2007). A functional analysis of the 2006 Canadian and 2007 Australian election debates. Argumentation \& Advocacy, 44, 36-48.

Benoit, W. L., \& Henson, J. R. (2009). A functional analysis of the 2008 Vice Presidential debate: Biden versus Palin. Argumentation \& Advocacy, 46, 39-50.

Benoit, W. L., \& Klyukosvki, A. (2006). A functional analysis of 2004 Ukrainian Presidential debates. Argumentation, 20, 209-225. http://dx.doi.org/10.1007/s10503-006-9007-x

Benoit, W. L., \& Sheafer, T. (2006). Functional theory and political discourse: Televised debates in Israel and United States. Journalism \& Mass Communication Quarterly, 83, 281-297. http://dx.doi.org/10.1177/107769900608300204

Benoit, W. L., Blaney, J. R., \& Pier, P. M. (2000). Acclaiming, attacking, and defending: A functional analysis of U.S. nominating convention keynote speeches. Political Communication, 17, 61-84. http://dx.doi.org/10.1080/105846000198512

Benoit, W. L., Delbert, J., Sudbrock, L. A., \& Vogt, C. (2010). A functional analysis of 2008 Senate and Gubernatorial TV spots. Human Communication, 13, 103-125.

Benoit, W. L., Hansen, G. J., \& Verser, R. M. (2003). A meta-analysis of the effects of viewing of U.S. presidential debates. Communication Monographs, 70, 335-350. http://dx.doi.org/10.1080/0363775032000179133

Benoit, W. L., Henson, J. R., Davis, J., Glantz, M., Phillips, A., \& Rill, L. (2013). Stumping on the Internet 2008 Presidential primary candidate campaign websites. Human Communication, 16, 1-12.

Benoit, W. L., McKinney, M. S., \& Stephenson, M. T. (2006). Effects of watching primary debates in the 2000 U.S. Presidential campaign. Journal of Communication, 52, 316-331. http://dx.doi.org/10.1111/j.1460-2466.2002.tb02547.x

Benoit, W. L., Pier, P. M., Brazeal, L. M., McHale, J. P., Klyokovski, A., \& Airne, D. (2002). The primary decision: A functional analysis of debates in presidential primaries. Westport, CT: Praeger.

Benoit, W. L., Webber, D. J., \& Berman, J. (1998). Effects of presidential debate watching and ideology on attitudes and knowledge. Argumentation \& Advocacy, 34, 163-173.

Benoit, W. L., Wen, W., \& Yu, T. (2007). A functional analysis of 2004 Taiwanese political debates. Asian Journal of Communication, 17, 24-39. http://dx.doi.org/10.1080/01292980601114521

Blencowe, A. (6 February, 2012). Haaviston homouden merkitystä pohdiskellaan. Yle Uutiset. Retrieved from: http://yle.fi/uutiset/haaviston_homouden_merkitysta_pohdiskellaan/5054560

Brazeal, L. M., \& Benoit, W. L. (2001). A functional analysis of Congressional television spots 1986-2000. Communication Quarterly, 49, 436-454. http://dx.doi.org/10.1080/01463370109385640

Brazeal, L. M., \& Benoit, W. L. (2006). On the spot: A functional analysis of Congressional television spots 1980-2004. Communication Studies, 57, 401-420. http://dx.doi.org/10.1080/10510970600945972

Choi, Y. S., \& Benoit, W. L. (2013). A functional analysis of the 2007 and 2012 French Presidential debates. Journal of 
Intercultural Communication Research, 42, 215-227. http://dx.doi.org/10.1080/17475759.2013.827584

Cienki, A. (2004). Bush's and Gore's language and gestures in the 2000 US Presidential debates. Journal of Language \& Politics, 3, 409-440. http://dx.doi.org/10.1075/jlp.3.3.04cie

Cmeciu, C., \& Patrut, M. (2010). A functional approach to the 2009 Romanian Presidential debates. Case study: Crin Antonescu versus Traian Băsescu. Journal of Media Research, 3, 31-41.

Cole, H. J., \& Hawthorne, J. (2013). Issue ownership trends and tensions in 2008: Obama, the transformative democrat? Argumentation \& Advocacy, 50, 72-88.

Hallamaa, T. (3 February, 2012). Vaalien suurin draama nähtiin jo ensimmäisellä kierroksella. Yle Uutiset. Retrieved from: http://yle.fi/uutiset/vaalien_suurin_draama_nahtiin_jo_ensimmaisella_kierroksella/5054329

Halmari, H. (2008). On the language of the Clinton-Dole presidential campaign debates. Journal of Language \& Politics, 7, 247-270. http://dx.doi.org/10.1075/jlp.7.2.04hal

Halonen, S. (2002). Ehdokasidentiteettien rakentuminen vuoden 2000 presidentinvaalien vaaliväittelyssä. Master's Thesis. University of Jyväskylä: Jyväskylä, Finland.

Herrero, J. C., \& Benoit, W. L. (2009). The abuse of attacks: A functional analysis of the 2008 Spanish Presidential debates. Conference paper. International Communication Association: 2009 Annual Meeting.

Hollihan, T. (2009). Arguments in the 2008 Presidential election. Argument \& Advocacy, 46, 1-5.

Hrbková, L., \& Zagrapan, J. (2014). Slovak political debates: Functional theory in a multi-party system. European Journal of Communication, 29, 735-744. http://dx.doi.org/10.1177/0267323114544864

Iranto, A. (27 January, 2012). Professori: TV-esiintyminen voi ratkaista vaalin. Yle Uutiset. Retrieved from: http://yle.fi/uutiset/professori_tv-esiintyminen_voi_ratkaista_vaalin/5053676

Isotalus, P. (2009). Agreement and disagreement in focus: A cultural perspective on televised election debates. In Wilkins, R., \& Isotalus, P. (Eds.), Speech Culture in Finland (pp. 191-208). Lanham, MD: University Press of America.

Isotalus, P. (2010). Cultural perspective on the analyses of interaction in Presidential debates-Comparing two models. Forensic, 95, 1-18.

Isotalus, P. (2011). Analyzing Presidential debates. NORDICOM Review, 32, 31-43.

Kaija, J., \& Malinen, M. (2007). Argumentointi YLE:n vaalitenteissä : miten pääehdokkaat ja haastattelija argumentoivat presidentinvaalien 2006 vaalitenteissä. Master's Thesis. The University of Jyväskylä: Jyväskylä.

Kinnunen, P. (3 August, 2011). Kuka haastaisi Niinistön? Yle Uutiset. Retrieved from: http://yle.fi/uutiset/kuka_haastaisi_niiniston/5401052

Kuivasmäki, A. (2000). Martti Ahtisaaren ja Elisabeth Rehnin viestintätyyli television vaaliohjelmissa vuoden 1994 presidentinvaaleissa. Master's Thesis. The University of Jyväskylä: Jyväskylä, Finland.

Lee, C., \& Benoit, W. L. (2004). A functional analysis of Presidential television spots: A comparison of Korean and American ads. Communication Quarterly, 52, 68-79. http://dx.doi.org/10.1080/01463370409370179

Lee, C., \& Benoit, W. L. (2005). A functional analysis of the 2002 Korean Presidential debates. Asian Journal of Communication, 15, 115-132. http://dx.doi.org/10.1080/01292980500118193

Lemert, J. B. (1993). Do televised Presidential debates help to inform voters? Journal of Broadcasting and Electronic Media, 37, 83-94. http://dx.doi.org/10.1080/08838159309364205

McKinney, M. S., \& Warner, B. R. (2013). Do Presidential debates matter? Examining a decade of campaign debate effects. Argumentation \& Advocacy, 49, 238-258.

Peifer, J. T., \& Holbert, R. L. (2013). Developing a systematic assessment of humor in the context of the 2012 U.S. general election debates. Argumentation \& Advocacy, 49, 286-300.

Pfau, M. (2002). The subtle nature of presidential debate influence. Argumentation \& Advocacy, 38, 251-261.

Rhea, D. (2012). There they go again: The use of humor in Presidential debates 1960-2008. Argumentation \& Advocacy, 49, 115-131.

Roitman, M. (2015). Constructing one's arguments based on refutations of the other's discourse. A study of the traditional Presidential debate: Chirac/Jospin (1995) versus Sarkozy/Royal (2007). Argumentation, 29, 19-32. http://dx.doi.org/10.1007/s10503-014-9332-4 
Schrott, P. R. (1990). Electoral consequences of "Winning” televised campaign debates. Public Opinion Quarterly, 54, 567-585. http://dx.doi.org/10.1086/269228

Straub, S. K., Beller, J. L., \& Hunt, T. W. (2012). I concur, you are absolutely correct that I am correct: Agreement as an argumentative strategy. Contemporary Argumentation \& Debate, 33, 1-26.

Tiittula L., Nuolijärvi, P., \& Isotalus, P. (2007). Halosen ja Niinistön esiintymistyylit television vaalikeskusteluissa. In Isotalus, P. \& Borg, S. (Eds), Presidentinvaalit 2006. (pp. 155-177). Helsinki, Finland: WSOY.

YLE. (23 January, 2012). Suomen seuraava presidentti on joko konservatiivi tai liberaali. Yle Uutiset. Retrieved from: http://yle.fi/uutiset/suomen_seuraava_presidentti_on_joko_konservatiivi_tai_liberaali/5053272

Zarefsky, D. (2008). Strategic maneuvering in political argumentation. Argumentation, 22, 317-330. http://dx.doi.org/10.1007/s10503-008-9096-9

\section{(cc) $\mathrm{BY}$}

This work is licensed under a Creative Commons Attribution 3.0 License. 